\title{
DNA Mapping in Growth and Developmental Disorders
}

John A. Phillips III,

Department of Pediatrics, Division of Genetics, Vanderbilt University School of Medicine, Nashville, USA

\begin{abstract}
DNA mapping techniques are being increasingly applied to familial and acquired disorders affecting growth and development. To understand the potential applications of these techniques, one must first have a good understanding of the components and basic structue of DNA, the genetic code, the basic structure of genes and the roles that various components of gene structure play in regulating gene expression. Following review of this basic information, a variety of DNA mapping techniques including in situ hybridization, Southern blotting, polymerase chain reaction amplification, DNA sequencing and linkage analysis will be covered. Applications of these techniques can enable mapping of unknown genes by detection of loss of allelic heterozygosity or use of linkage analysis and genetic maps. With increasing ease, mutations such as deletions, expansions, rearrangements and point mutations can be detected in diseases such as congenital adrenal hyperplasia, cystic fibrosis, diabetes insipidus, growth hormone deficiency, fragile $\mathrm{X}$ syndrome, Laron dwarfism and Turner syndrome. From this discussion, a better understanding of methods of gene localization, uses of genetic maps and rapid, convenient methods to detect a variety of molecular derangements causing familial disorders affecting growth and development will be gained.
\end{abstract}

Key words: DNA analysis, gene mapping, linkage and PCR analysis

\section{Introduction}

This material will review DNA structure and a variety of techniques that are used in mapping genes that are important in growth and development. Examples of applications will include use of PCR amplification, Southern blotting, linkage analysis and DNA se-

Correspondence: Dr. John A. Phillips III, Vanderbilt University School of Medicine Department of Pediatrics, Division of Genetics DD-2205 MCN Nashville, TN USA 37232-2578 quencing to map and detect derangements of the arginine vasopressin, growth hormone, growth hormone receptor, insulin, insulin receptor, Pit-1 and vitamin D receptor genes. From these examples the reader should better understand the molecular derangements causing some forms of familial diabetes insipidus, growth hormone deficiency, diabetes mellitus, Laron dwarfism, panhypopituitary dwarfism and vitamin $\mathrm{D}$ resistant rickets in humans. 


\section{Biochemistry of DNA}

Components of DNA: DNA is composed of nucleotides which are made up of bases and deoxyribose sugar molecules. The purine and pyrimidine bases are shown in the table below.

\section{Purines $\quad$ Adenine (A) Guanine (G) \\ Pyrimidines Cytosine (C) Thymine (T)}

The sugar component of DNA is a pentose (2-deoxyribose) that is connected at position 1 to one of the nitrogenous bases (A, C, G or T) (see Fig. 1). Also, note that the addition of a hydroxy1 group to carbon two of 2deoxyribose converts it to ribose which is the sugar that is found in RNA. This sugar hydroxylation accounts for the alkali sensitivity of RNA as opposed to the resistance of DNA.

Structure of the DNA Molecule: The DNA molecule consists of nucleotides (made up of a base and a 2-deoxyribose sugar) that are polymerized in a series of 5'-3' sugar phosphate links (see Fig. 1). This sugar phosphate backbone is composed 5'-3' of 1) a phosphate molecule, 2) the 5' carbon of the deoxyribose molecule, 3) the 3' deoxyribose carbon which attaches to 4) the next phosphate molecule. Note that the bases are attached to carbon 1 of 2-deoxyribose and project away from the sugar-phosphate backbone.

Hydrogen bonding between $\mathrm{A} \cdot \mathrm{T}$ and $\mathrm{G} \cdot \mathrm{C}$ bases on complementary DNA strands stabilizes formation of the double helix. Note that $\mathrm{A}=\mathrm{T}$ pairing forms two hydrogen bonds while $\mathrm{G} \equiv \mathrm{C}$ pairing forms three hydrogen bonds. Also note that the hydrogen bonding occurs between the bases on complementary strands that run in anti-parallel directions i.e. $5 ' \rightarrow 3$ ' on one strand and $3^{\prime} \leftarrow 5$ ' on the complementary strand. Finally, as the temperature is increased denaturation of the two DNA strands occurs first between $\mathrm{A}=\mathrm{T}$ pairs then between $\mathrm{G} \equiv \mathrm{C}$ pairs because of the higher

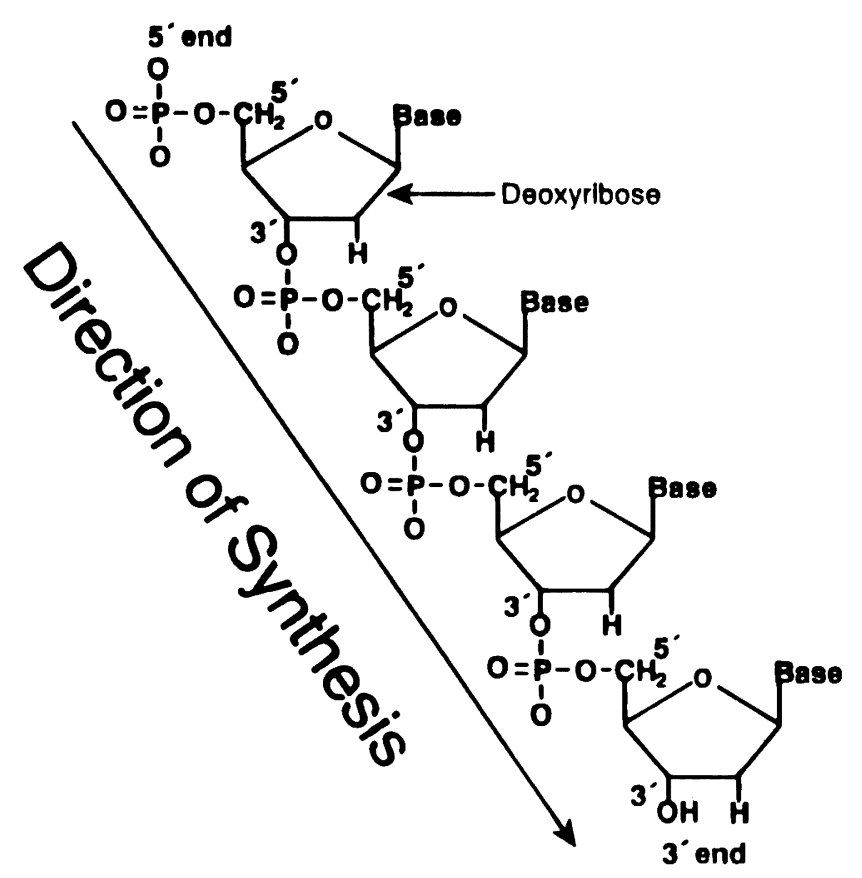

Fig. 1. Schematic representation of a DNA strand showing the bases, deoxyribose sugar and 5' to 3' direction of synthesis.

stability of the latter. Both types of base pairs melt at higher temperatures than mispaired $(A \cdot C$ and $G \cdot T)$ sequences. These differences in melting temperature are exploited by a variety of methods in the detection of various types of mutations.

\section{Methods of Mapping}

Molecular tools used to map and examine endocrine disorders include restriction endonuclease analysis, the polymerase chain reaction and DNA sequence analysis.

\section{A. Restriction Endonuclease Analysis}

Restriction endonuclease analysis can be used to detect gene deletions, certain point mutations, and in linkage analysis to determine if a gene and a genetic endocrine disorder are transmitted together. Restriction endonucleases are bacterial enzymes that recognize and cleave double-stranded DNA at specific recognition sequences. This property 
enables them to cut the long strands of cellular DNA into fragments of reproducible size. If the restriction endonuclease is one like EcoRI it will cut DNA leaving the ends of the two strands offset from each other (1). This overhang of one DNA strand over the other produces "sticky ends". Such "sticky ends" promote pairing with fragments also cut with EcoRI to form recombinant molecules. Other endonucleases, such as $\underline{\mathrm{Ha}} \mathrm{III}$ cut the ends off equally producing so called "blunt ends".

\section{Chromosome Specific Probes}

An example of the use of restriction endonuclease analysis to detect the presence or absence of an extra chromosome is Turner syndrome. Usually the karyotype shows a 45 , $\mathrm{X}$ pattern but some subjects have additional chromosomal fragments. The fragments represent, in some cases, an X chromosome with a deletion or alternatively a portion of a $\mathrm{Y}$ chromosome. Distinction between these two is important because the presence of $\mathrm{Y}$ chromosomal material predisposes to gonadoblastomas.

Fig. 2 illustrates the detection of $\mathrm{Y}$ chromosomal fragments by restriction analysis. The solid circle represents a Turner syndrome subject. Her chromosomes included a normal $\mathrm{X}$ and a fragment (shown above). The fragment is smaller than either an $\mathrm{X}$ or a $\mathrm{Y}$ (compare to her father's $Y$ at far right). A DNA probe containing a $\mathrm{Y}$ chromosome sequence was used to examine restriction fragments from a control female, the subject's mother, the subject, and the subject's father (2-3). DNA isolated from peripheral blood was digested with EcoRI. The resulting DNA fragments are separated by electrophoresis in agarose gels, the large DNA fragments were located at the top of the gel and the small fragments at the bottom. The DNA fragments are transferred or blotted from the agarose gel to a filter membrane as described by Southern and the filter-bound DNA is then hybridized to a solution containing a $\mathrm{Y}$ chromosome probe $\left({ }^{32} \mathrm{P}\right.$-radiolabeled single-stranded DNA or RNA copy of sequences specific to the $\mathrm{Y}$

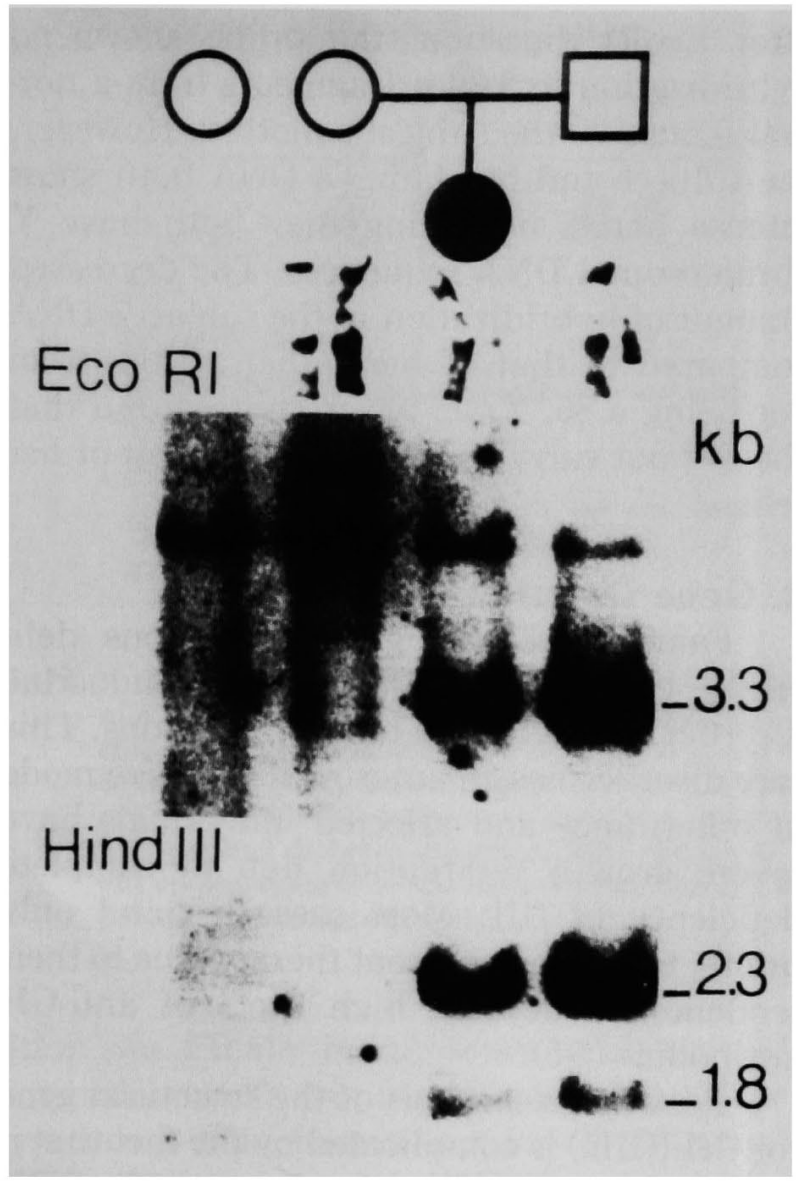

Fig. 2. Analysis of chromosomes and DNA from a Turner syndrome subject. A portion of the $45 \mathrm{X}+$ frag karyotype of the subject (solid circle) is shown above. DNA analysis using a $\mathrm{Y}$ chromosome specific probe detects $Y$-specific sequences in DNA from the patient and her father as shown below (3).

chromosome). The probe molecules anneal to their complementary sequences on the filter to form double-stranded DNA. One strand of these molecules is from the subject's DNA while the other strand is the radiolabeled probe. After hybridization, the filter is washed to remove excess probe and subjected to autoradiography. The DNA fragments that annealed to the probe appear as bands on the developed film. By comparing the location of these bands with that of markers of known molecular weight, the size of hybridizing DNA fragments is determined. In Fig. 2 obtained 
after EcoRI digestion, the probe shows no hybridization to $3.3 \mathrm{~kb}$ fragments from a normal female or the subject's mother. However, the subject and her father's DNA both show intense bands indicating they both have $Y$ chromosomal DNA sequences. The decreased amount of hybridization in the subject's DNA compared to that of her father results from her being a $45, \mathrm{X} / 46, \mathrm{X}+$ frag mosaic so that she did not carry the $\mathrm{Y}$ fragment in all of her cells.

\section{Gene Deletions}

Familial isolated growth hormone deficiency type $1 \mathrm{~A}$ (IGHD 1A) is an endocrine disorder that is caused by gene deletions. This rare disorder has an autosomal recessive mode of inheritance and affected individuals have severe growth retardation due to complete deficiency of GH. Most cases respond only briefly to $\mathrm{GH}$ replacement therapy due to their tendency to develop high titers of anti-GH antibodies (4-5).

Restriction analysis of the structural gene for GH (GH1) is complicated by the fact that it is one of the five $\mathrm{GH}$ related genes (5'-GH1: CSHP1:CSH1:GH2:CSH2-3') contained in the $\mathrm{GH}$ gene cluster. Although these various genes share extensive sequence homology, only the GH1 locus encodes GH. The CSHP1 gene is of unknown function and encodes a chorionic somatomammotropin hormone (CSH)-like peptide, whereas $\mathrm{CHS} 1$ and $\mathrm{CSH} 2$ encode $\mathrm{CSH}$, and $\mathrm{GH} 2$ encodes a variant $\mathrm{GH}$ of unknown function whose gene contains an internal BamHI site. The GH1 gene is flanked by consistent BamHI sites that are $3.8 \mathrm{~kb}$ apart. While the CSHP1, CSH1, GH2, and CSH2 genes are sufficiently homologous to hybridize to the GH1 probe, they all are contained in BamHI derived fragments that differ in size from that of GH1. Autoradiograms of DNAs from IGHD 1A subjects lack the $3.8 \mathrm{~kb}$ fragments that normally contain the GH1 genes (Fig. 3). In addition, the intensity of the $3.8 \mathrm{~kb}$ bands in DNA from the heterozygous parents is intermediate between that of controls and their affected children. These results show

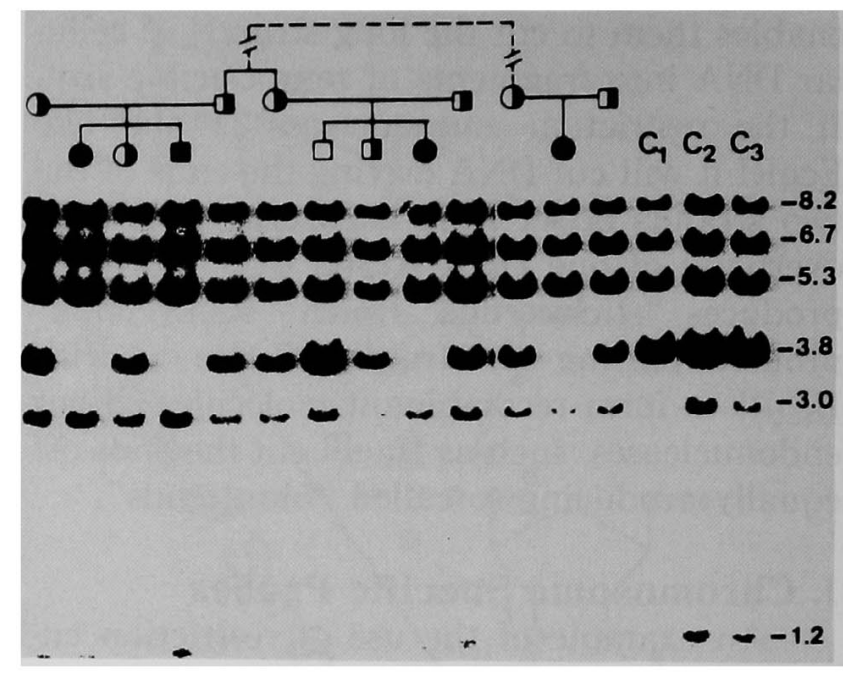

Fig. 3. Autoradiogram patterns of DNA from three Swiss families and three controls $\left(\mathrm{C}_{1-3}\right)$ following digestion with BamHI and hybridization to the GH1 cDNA probe. Note that the affected individuals lack and their parents have decreased amounts of the $3.8 \mathrm{~kb}$ fragment (GH1 gene) as compared to controls (4).

that IGHD 1A subjects are homozygous and their parents are heterozygous for $\mathrm{GH} 1$ gene deletions. Since these deletions preclude production of any $\mathrm{GH}$, affected individuals tend to be immunologically intolerant to exogenous $\mathrm{GH}$.

\section{Point Mutations}

The detection of certain insulin gene mutations is an example of the detection of point mutations by restriction analysis. Several such mutant insulins have been reported. The clinical features seen in heterozygotes include hyperglycemia with high insulin levels, in the absence of insulin antagonists or receptor antibodies, and a normal response to exogenous insulin. The mutant insulin first described has an $88 \%$ decrease in biological potency $(6-8)$. This mutant insulin was found to have a leucine substituted for phenylalanine at residue 25 in its $B$ chain and is called (Leu ${ }^{\mathrm{B} 25}$ insulin) (9). DNA analysis of the $\mathrm{Leu}^{\mathrm{B} 25}$ insulin gene revealed a nucleotide substitution at position 402. Interestingly, the restriction enzyme Mbo II which cleaves the 


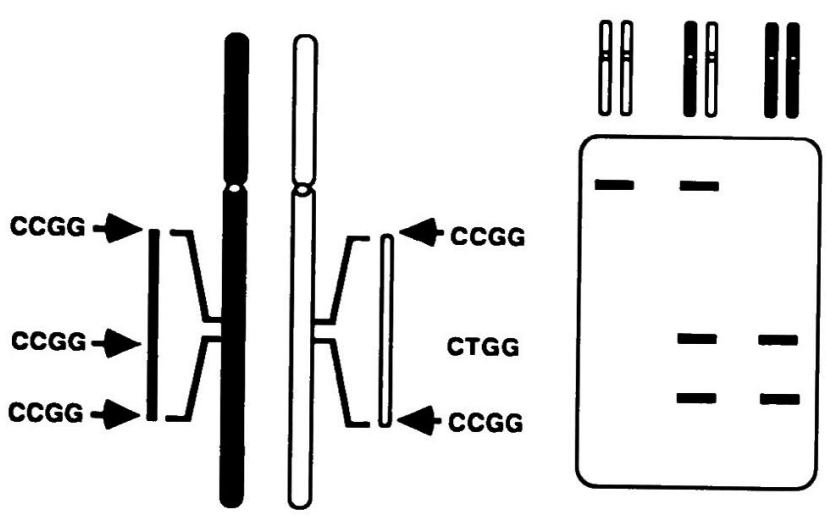

Fig. 4. Schematic representation of a restriction fragment length polymorphism and the resulting autoradiogram patterns.

normal insulin gene at this point is unable to cleave $\mathrm{Leu}^{\mathrm{B} 25}$ insulin because of its nucleotide hange. Thus, DNA from a control yield fragments of 336 and $555 \mathrm{bp}$ when hybridized to an insulin gene probe. An individual heterozygous for $\mathrm{Leu}^{\mathrm{B25}}$ insulin will have a $891 \mathrm{bp}$ fragment (not seen in controls) because $\mathrm{Mbo}$ II cannot cut at the site that separates the 336 and $555 \mathrm{bp}$ fragments (10-11). A second mutant insulin (Ser ${ }^{\mathrm{B24}}$ insulin) has a serine for phenylalanine substitution. This mutation can also be detected because it prevents cleavage by MboII (12).

\section{Linkage Analysis}

Studies of familial diabetes insipidus are an example of mapping the gene responsible for an endocrine disorder by linkage analysis. Linkage analysis is usually done using restriction fragment length polymorphisms (RFLPs) (Fig. 4). RFLPs result from DNA polymorphisms or base differences that normally occur without any clinical consequences about 1 in every 200 to 500 nucleotides not encoding proteins (13). These differences are usually single nucleotide substitutions some of which can affect a restriction site. A second or insertion/deletion type of DNA polymorphism also called variable numbers of tandem repeats or dinucleotide repeats can alter the DNA fragment size without affecting the enzyme recog-

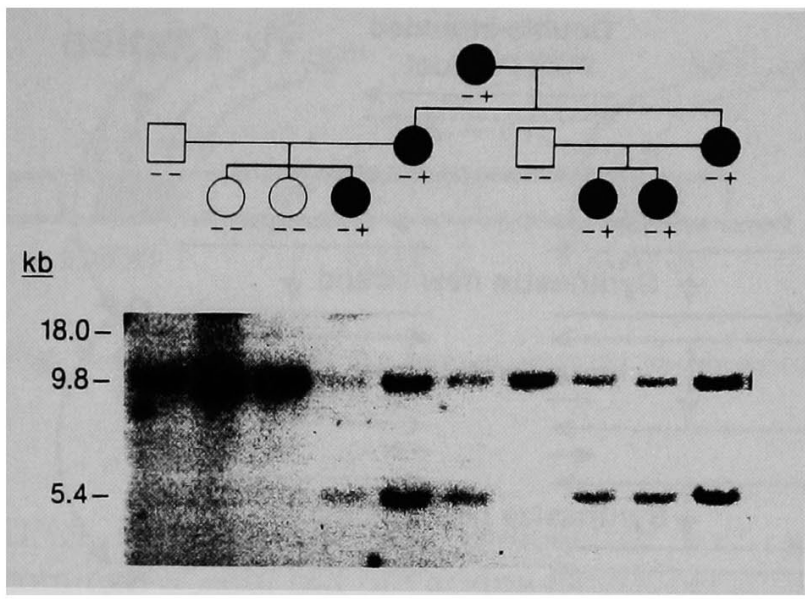

Fig. 5. Autoradiogram of genomic DNA from members of a family after digestion with XbaI and hybridization with radiolabelled OT-NPI which is close to the AVP gene. Individuals with solid symbols are affected with autosomal dominant neurohypophyseal diabetes insipidus. Note the apparent co-segregation of the disorder and the DNA polymorphism detected (15).

nition site. Finally the presence or absence of a pseudogene (a nonfunctional gene whose sequence is homologous to a functional gene) changes the length of the DNA fragment that is bounded by two restriction sites (14).

In an autosomal dominant form of diabetes insipidus due to arginine vasopressin deficiency (ADNDI) we could not detect deletions, insertions or rearrangements of an arginine vaspopressin (AVP) allele (15). Using an XbaI RFLP closely linked to AVP we found apparent cosegregation with ADNDI in two families (Fig. 5). The overall LOD score of 2.70 indicates that the genetic locus for ADNDI maps within or near the AVP locus and sug. gests that a defective AVP allele may cause this form of diabetes insipidus.

\section{B. Polymerase Chain Reaction}

The polymerase chain reaction (PCR) technology is an important new tool for DNA diagnosis (Fig. 6) (16-18). This procedure enables the gene selected for study to be enzymatically amplified relative to the remainder of the genomic DNA. This amplification can yield $10^{7}-10^{8}$ copies of the original segment 


\section{Phillips III}

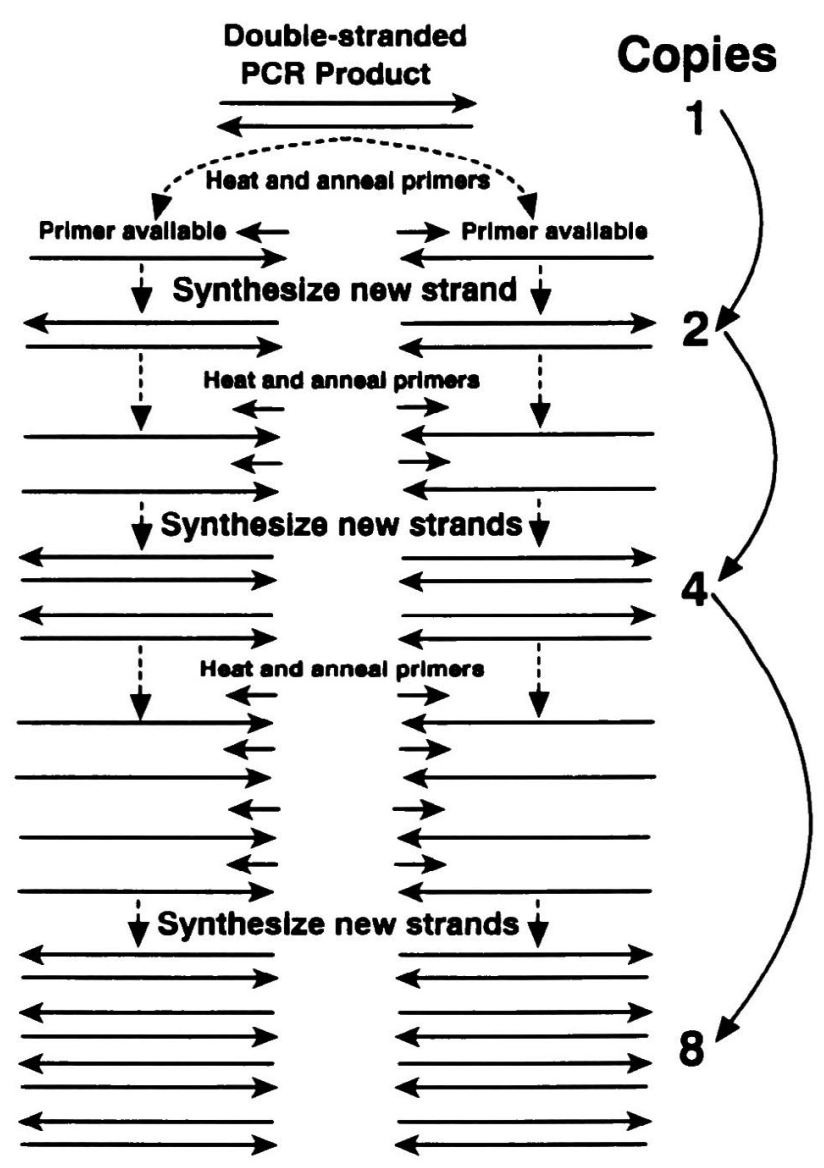

Fig. 6. Schematic representation of the polymerase chain reaction (PCR) amplification reaction. Note the rapid accumulation of gene segments bounded by the primers after the second cycle of amplification.

which can allow direct visualization of the fragments under study thereby precluding the need for Southern blots and radiolabeled probes. PCR amplification makes it possible to amplify specific sequences directly from complex genomic samples without cloning. This ability has led to the development of many new techniques of gene analysis and has revolutionized the way in which inherited disorders are studied. Mutant alleles can be PCR amplified and then rapidly characterized using a combination of segregation analysis, gene scanning, direct DNA sequencing, and RNA transcript analysis (16-18).

An example of the utility of PCR amplification is detection of $\mathrm{Y}$ chromosome frag-

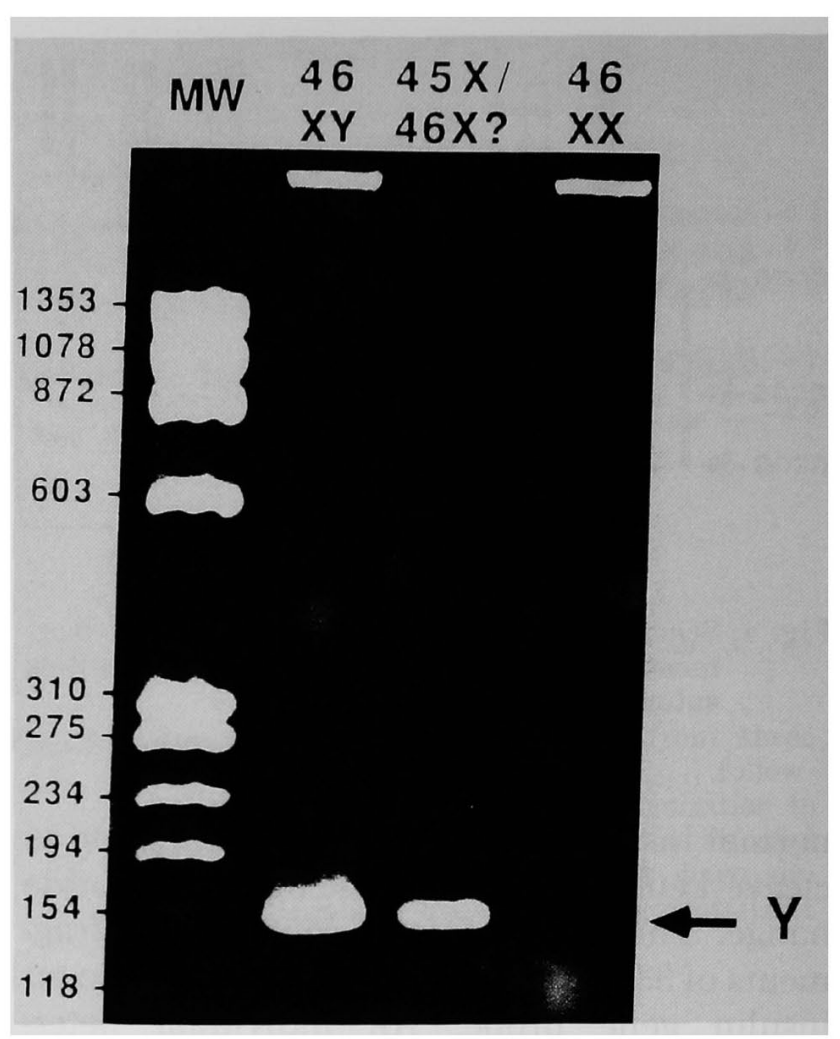

Fig. 7. Polyacrylamide gel analysis of PCR products of DNA from a family similar to that shown in Fig. 1 following amplification using Y-chromosome specific primers. Note the detection of $Y$ specific sequences in the amplification products of the patient and her father.

ments in Tuner syndrome. In a case similar to that shown in Fig. 2 we have used the PCR and $\mathrm{Y}$ specific oligonucleotide primers to determine if the chromosomal fragment was derived from an $\mathrm{X}$ or $\mathrm{Y}$. Note the affected subject who was mosaic for $45, \mathrm{X} / 46 \mathrm{X}+$ frag has easily detectible $\mathrm{Y}$ chromosomal material in DNA derived from peripheral blood (Fig. 7). Such studies can be done in 3 hours, require small alquots $(1-2 \mu \mathrm{L})$ of blood, and avoid the use of Southern blots or probes.

\section{DNA Sequencing}

DNA sequencing is usually done by the dideoxy method using DNA polymerase to synthesize a complementary radioactive copy (Fig. 8) (19). During the DNA polymerase reaction 2', 3' dideoxynucleotides of $\mathrm{A}, \mathrm{C}, \mathrm{G}$, or $\mathrm{T}$ are added to four separate reactions 


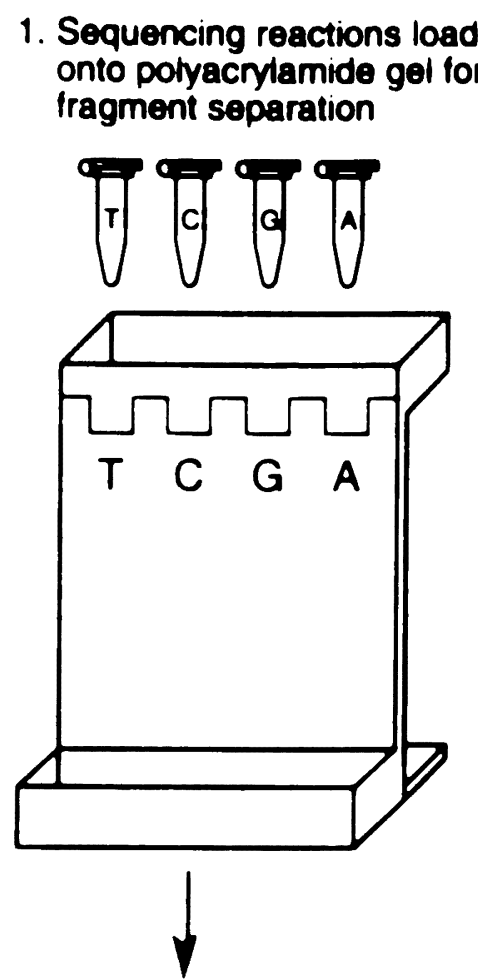

2. Sequence read (bottom to top) from gel autoradiogram

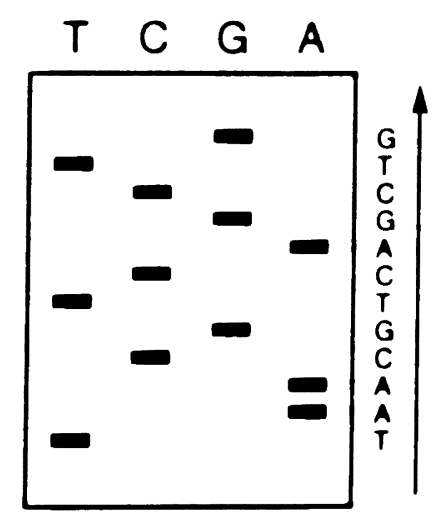

Fig. 8. Schematic depiction of DNA sequencing by the dideoxy method. Following the DNA polymerase reaction in the presence of dideoxy analogs, the four reaction products are subjected to gel electrophoresis and autoradiography enabling sequence deduction.

containing one of the deoxyribonucleotides radiolabeled with ${ }^{32} \mathrm{P}$ ro ${ }^{35} \mathrm{~S}$. When one of the dideoxynucleotides is incorporated, the 3 ' end of the reaction is no longer a substrate for chain elongation, and the growing DNA chain is terminated. Thus in each of these four separate reactions there is a population of

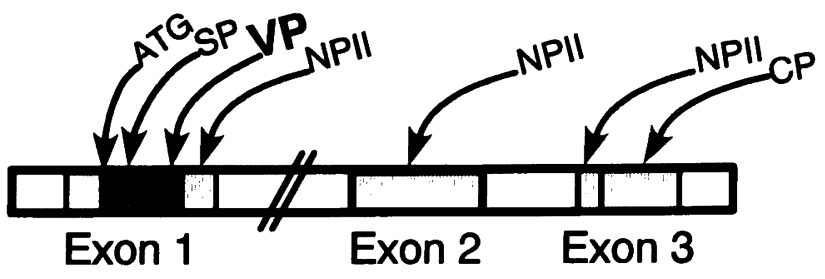

Fig. 9. Organization of the human arginine vasopressin (AVP-NPII) gene.

DNA molecules that is radioactive with a common 5' end, but of varying length because of the incorporation of a specific 3' end. Next, each of the four reaction products are subjected to electrophoresis and autoradiography and sequence deduction are performed. Comparison of the mutant and wild-type sequence allows deduction of the mutation. Sequencing not only identifies the mutation but can enable derivation of short oligonucleotide sequences that can be used as probes to detect the presence of that specific mutation in genomic DNA samples from other individuals.

\section{Status of Molecular Endocrinology}

For a variety of endocrine disorders including diabetes insipidus, GH deficiency, diabetes mellitus, and vitamin $\mathrm{D}$ resistant rickets there are varying amounts of data from DNA studies. I will briefly summarize selected aspects of these data and their conclusions.

\section{A. Diabetes Insipidus (DI)}

Molecular studies have clarified the basis of genetic forms of DI. These have clarified the structure of the AVP gene (Fig. 9) and assigned it to chromosome 20 (20). Recently, a number of mutations causing autosomal dominant DI have been identified (Fig. 10) (21-24). The AVP gene (AVP-NPII) contains AVP in exon 1 and its carrier protein (neurophysin or NPII) in exons 1-3. Cosegregation of the ADNDI phenotype and DNA polymorphisms closely linked to the AVP gene was found in two unrelated families, suggesting that muta- 


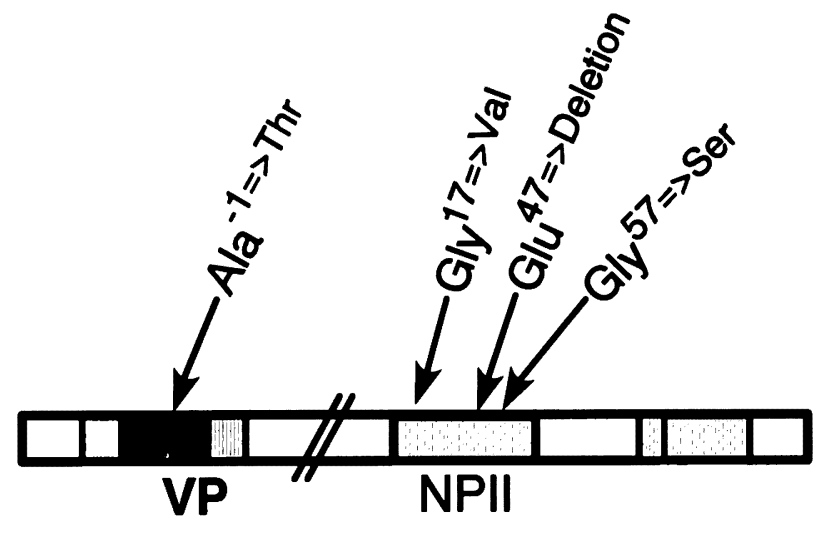

Fig. 10. The location and types of mutations found in the human AVP gene associated with autosomal dominant diabetes insipidus.

tions in AVP cause somes cases of ADNDI (15). Two mutations in NPII (Gly $\rightarrow$ valine and Gly $\rightarrow$ ser at codons 17 and 57) causing ADNDI have been reported $(21,22)$. $\mathrm{Gly}^{17}$ mutation is thought to perturb the conformation and selfaggregation of AVP-NPII precursors that are required for normal intracellular transportation and secretion (21). The Gly ${ }^{57}$ mutation is speculated to perturb NPII's ability to transport or protect AVP from proteolytic degradation (22). Recently, a novel mutation that affects AVP rather than NPII, was reported that should affect cleavage of AVP from its precursor (prepo AVP) as an additional cause of ADNDI (23).

\section{B. Severe GH Deficiency}

The most severe form of IGHD called IGHD IA, has an autosomal recessive mode of inheritance. Affected individuals occasionally have short lengths at birth and hypoglycemia in infancy, but uniformly develop severe dwarfism by 6 months of age. In response to replacement therapy with exogenous $\mathrm{GH}$, IGHD IA subjects have a strong initial anabolic and growth response that is frequently followed by the development of anti-GH antibodies in sufficient titer to block the response to $\mathrm{GH}$ replacement $(25-27)$. These features led Illig et al to hypothesize that IGHD IA caused complete prenatal and post- natal deficiency of endogenous $\mathrm{GH}$ secretion which resulted in an immune response to exogenous GH (27).

Deletions. Initially, all individuals with IGHD IA were found to be homozygous for $\mathrm{GH} 1$ gene deletions and developed anti-GH antibodies with treatment $(4,28)$. Subsequently, additional cases with $\mathrm{GH} 1$ gene deletions have been described who also have complete $\mathrm{GH}$ deficiency, but respond well to $\mathrm{GH}$ replacement $(4,29)$. Thus, the clinical outcomes of subjects with the same molecular findings (homozygosity for $\mathrm{GH} 1$ gene deletions) vary making the presence of anti-GH antibodies an inconsistent finding in IGHD IA cases.

At a molecular level, Southern blot analysis showed deletions of $\sim 6.7,7.0$ or $7.6 \mathrm{~kb}$ with most $\sim 75 \%$ being $6.7 \mathrm{~kb}$ (4). DNA sequence analysis of the fusion fragments associated with $\mathrm{GH} 1$ gene deletions have shown that homologous recombination between sequences flanking the GH1 gene cause these deletions (30-32). This same mechanism has been demonstrated to cause deletions of the $\beta$ globin and LDL receptor genes in some subjects with $\beta$-thalassemia or familial hypercholesterolemia, respectively. Currently, GH1 gene deletions are detected using polymerase chain reaction (PCR) amplification of the homologous regions flanking the $\mathrm{GH} 1$ gene and the fusion fragments associated with $\mathrm{GH} 1$ gene deletions (Fig. 11) (31-32). Since the fusion fragments associated with $6.7 \mathrm{~kb}$ deletions differ in the size of fragments produced by certain restriction enzymes (see Sma I sites indicated by solid circle in Fig. 11) homozygosity or heterozygosity for these deletions can be easily detected by enzyme digestion of PCR products (31-33). A variety of studies suggest that $13-15 \%$ of subjects with severe IGHD ( $>-4.5 \mathrm{SD}$ in height) have GH1 gene deletions (4,30-33). Recently, frameshift and nonsense mutations have also been found in subjects with the IGHD IA phenotype so that this disorder may be best described as complete $\mathrm{GH}$ deficiency due to $\mathrm{GH} 1$ gene defects, rather than gene deletions alone (34-35). 


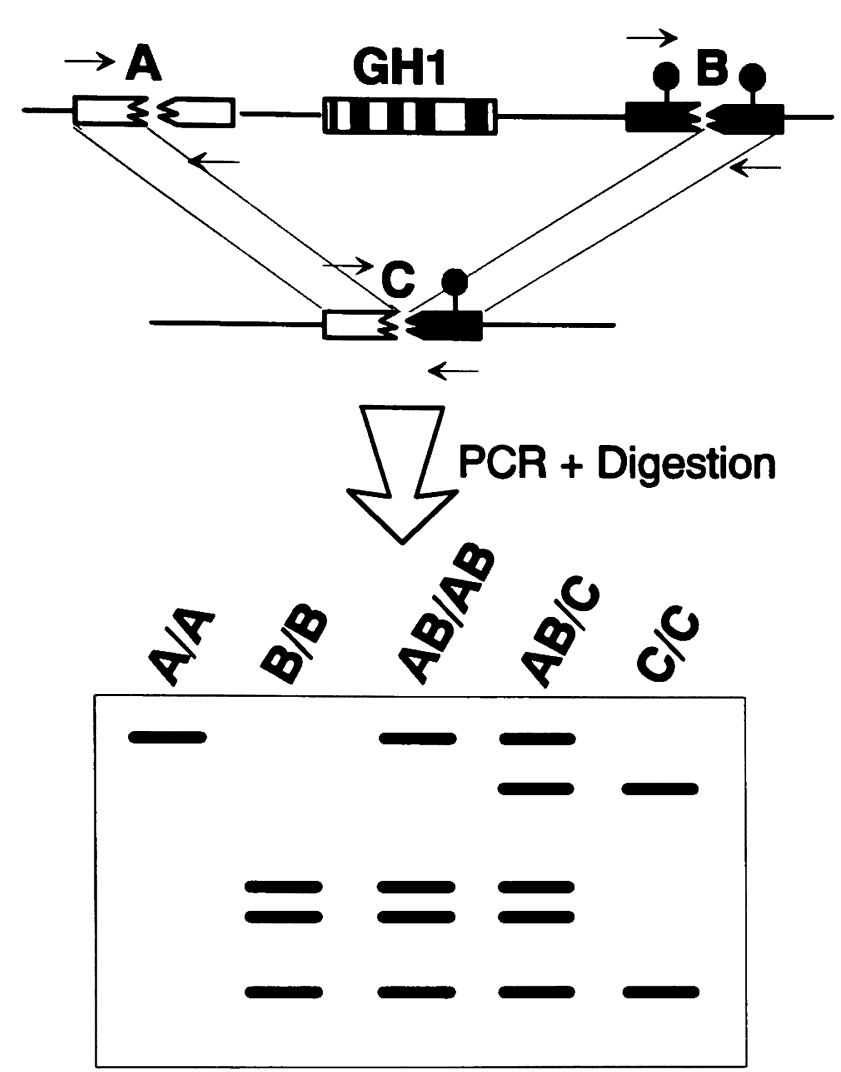

Fig. 11. PCR amplification of homologous sequences that flank the GH1 gene using a single set of oligonucleotide primers. Note that the 5' and 3' homologous sequences (labelled A and B) differ in the location of restriction sites (indicated by solid circles). The sites also differ from those on junction or fusion fragments (labelled $\mathrm{C}$ ) shown below that arise during recombination events that produce GH1 gene deletions (18).

\section{Laron Dwarfism}

The first examples of $\mathrm{GH}$ receptor or GHR mutations reported were deletions of portions of the gene encoding the extracellular domain (Fig. 12) (36-37). Southern blotting showed altered restriction patterns of the GHP genes from patients with Laron syndrome who had no detectable $\mathrm{GH}$ binding protein (GHBP) and very low levels of IGF- I . While these and other studies were interpreted as showing deletions of exons 3, 5-6 and part of 4 from the GHR gene, the mechanism by which these two non-contiguous deletions arose remains unclear. In two of nine patients studied by

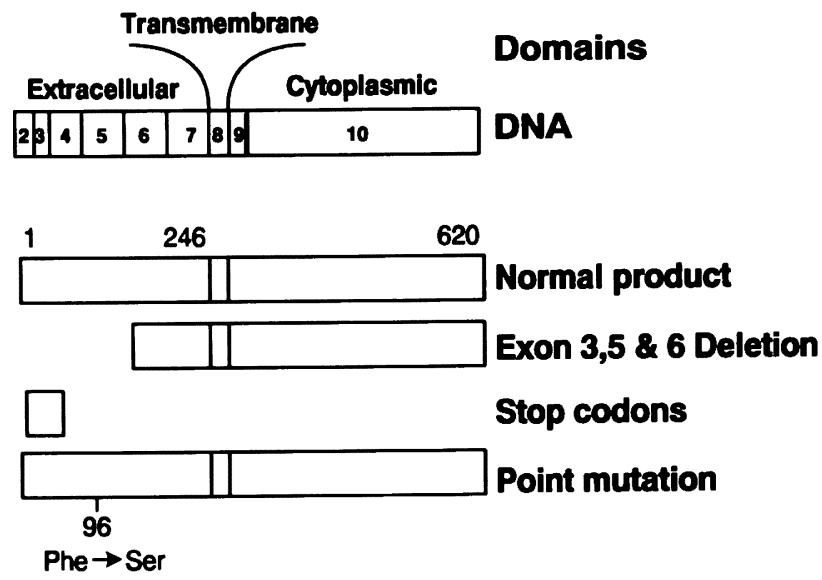

Fig. 12. Schematic representation of the GH receptor (GHR) gene showing the relationship of various exons to the extracellular, transmembrane and cytoplasmic GHR domains. Locations of deletions and selected point mutations are shown below.

Godowski et al. GHR deletions were found and JS Parks detected GHR deletions in five of nine of the Laron syndrome probands studied (36-37).

Multiple point mutations have been detected within the GHR gene (Fig. 13) (38-40). Amselem et al detected a $\mathrm{T}$ to $\mathrm{C}$ substitution that converts the 96th residue of the extracellular domain from phenylalanine to serine (39). Duquesnoy et al. demonstrated that cells transfected with this mutant cDNA lacked GH binding activity (40).

Two different stop codon mutations of GHR genes in Laron dwarf patients have been reported (38). In a patients of Northern European origin, a cysteine (TGC) $\rightarrow$ stop codon (TGA) mutation was detected at codon 38 in exon 4 (Fig. 13), and an arginine (CGA) $\rightarrow$ stop codon (TGA) mutation was found at codon 43 in exon 4 of two Mediterranean patients who were products of consanguineous marriages. Both stop codons truncate the GHR protein and delete most of its GHBP domain and all of its transmembrane and intracellular domains. These findings are consistent with the lack of GHBP in each of the patients with Laron syndrome. The mechanism of the CGA to TGA mutation is consistent with deamination 


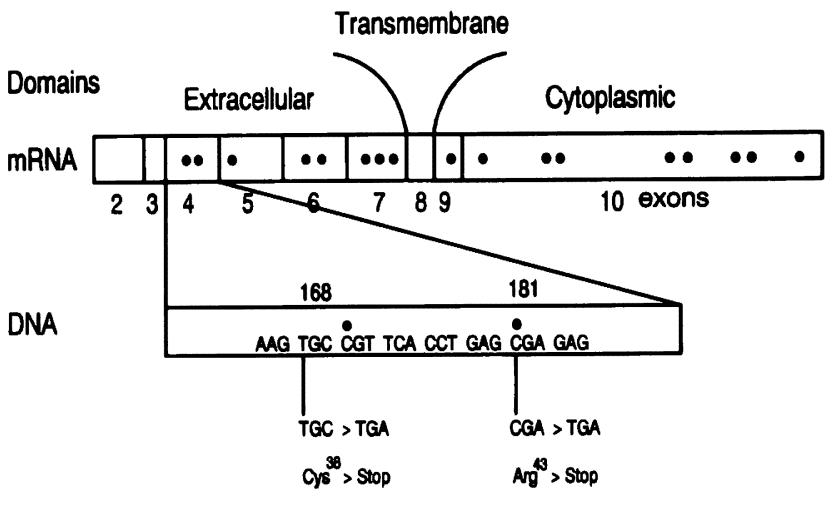

Fig. 13. Schematic representation of the GHR gene showing the locations of $\mathrm{CpG}$ dinucleotides as small circles. Segments of normal sequence and selected mutations are shown below.

of 5-methyl-cytosine that preferentially occurs in $\mathrm{CpG}$ dinucleotides. Such dinucleotides often represent "hot-spots" for CG to TG or CG to CA mutations, and 17 occur within the GHR gene (Fig. 13). Two of these, at nucleotides 181 and 703, occur in CGA codons that could yield stop codons $(36,38-39)$.

Rosenbloom et al. identified 20 patients with Laron syndrome in an inbred population of Spanish extraction in Southern Ecuador (41). These patients were -6.7 to -10 SDS below the mean height and had limited elbow extension, blue sclera, short limbs, hip degeneration, acrohypoplasia and normal or superior intelligence. To determine the associated defect in the GHR gene, Berg et al. used denaturing gradient gel electrophoresis (DGGE) to analyze each exon of the GHR gene (42). Unusual fragments derived from exon 6 showed abnormal mobility and DNA sequencing showed an $A \rightarrow G$ substitution in the third position of codon 180, which is 24 nucleotides from the 3 ' end of exon 6 . While this mutation does not cause an amino acid substitution, it produces a consensus 5' splice sequence within exon 6 . The resulting near consensus donor splice site within exon 6 causes aberrant splicing and deletion of eight amino acids of the 3 ' end of exon 6 . Deletion of these residues is thought to reduce the function of the GHBP molecule (42).

\section{Panhypopituitary Dwarfism}

Panhypopituitary dwarfism is characterized by deficiency of one or more of the other pituitary trophic hormones (ACTH, FSH, LH or $\mathrm{TSH}$ ) in addition to $\mathrm{GH}$ deficiency. While the great majority of cases are sporadic, there are both autosomal recessive and $\mathrm{X}$-linked forms (4). Recently, at least four different Pit-1 mutations have been found in humans in a subtype of panhypopituitary dwarfism associated with GH, PrL and TSH deficiency. These include, first, a $\mathrm{C} \rightarrow \mathrm{T}$ substitution in codon 172 which changes a CGA (arginine) $\rightarrow$ TGA (stop) (43). Second, a patient heterozygous for a $\mathrm{G} \rightarrow \mathrm{T}$ substitution in codon 271 was reported. The mechanism of the dominant effect of this GGG (arginine) $\rightarrow$ TGG (tryptophan) mutation is not completely understood (44). The third and fourth Pit-1 mutations were found in two Dutch families in which affected individuals had postnatal growth failure with complete deficiencies of GH and PrL, while their T4 levels were low prior to or following $\mathrm{GH}$ replacement (45-46). The family having normal T4 levels prior to $\mathrm{GH}$ replacement, were homozygous for a $\mathrm{G} \rightarrow \mathrm{C}$ substitution in codon 158 changing GCA (alanine) $\rightarrow$ CCA (proline). This mutation interferes with formation of Pit-1 homodimers and dramatically reduces the altered Pit-1's ability to activate transcription. In the family with low T4 levels, the affected children were genetic compounds with one deleted and one Pit-1 gene with the previous mutation. These cases emphasize the importance of determining PrL levels as well as TSH responses to $\mathrm{TRH}$ administration in evaluating panhypopituitarism. Since GH and TSH deficiency often occurs together, finding low PrL levels and failure of subjects to have TSH responses should raise the question of their having Pit-1 gene defects.

\section{E. Diabetes Mellitus}

Recent molecular genetic investigations have begun to unravel the suspected molecular heterogeneity and pathogenesis of diabetes 
mellitus. Using a variety of molecular techniques, specific nuclear and mitochondrial DNA abnormalities have been identified (see Table 1) (47-61). Interestingly, genes important in causing susceptibility to or protection from insulin dependent diabetes have been elucidated within the HLA-D and the insulin gene regions. One group of patients with maturity onset diabetes mellitus of the young or MODY have been found to have missense or nonsense mutations of the glucokinase gene, while a second group demonstrated linkage to the ADA (adenosine deaminase) locus on chromosome $20 \mathrm{q}$ and a third group showed no linkage to either locus. In the maternally inherited syndrome of diabetes mellitus and deafness a deletion and a point mutation of mitochondrial DNA (mtDNA) have been found. Finally patients with several insulinresistance syndromes have been found to have mutations in the insulin receptor gene. These recent discoveries (Table 1) demonstrate the heterogeneity of diabetes mellitus and provide the potential to use molecular techniques in making early preclinical diagnosis as well as more accurate determinations of risk to develop diabetes mellitus possible in certain families (47-61).

\section{F. Vitamin D Resistant Rickets}

Vitamin D resistant rickets is an autosomal recessive disorder which is characterized by a target orgat resistance to the action of 1,25-dihydroxyvitamin $\mathrm{D}_{3}$. Interestingly, while the intracellular vitamin $D$ receptor (VDR) from affected individuals in some families displays normal binding of 1 , 25dihydroxyvitamin $\mathrm{D}_{2}$ it has decreased affinity for DNA (62). To determine the status of this biologically inactive VDR gene Hughes et al PCR amplified and sequenced exons 2 and 3. Sequence analysis showed single base substitutions that destabilize the $Z N$ finger domain of the mutant VDR (62).
Table 1.

\begin{tabular}{|c|c|c|c|c|}
\hline \multirow[b]{2}{*}{ Type } & \multirow[b]{2}{*}{ Gene } & \multicolumn{3}{|c|}{$\begin{array}{l}\text { GENES AND REGIONS CONTRIBUTING TO } \\
\text { DLABETES MELLITUS }\end{array}$} \\
\hline & & Chromosome & Type of Abnormality & Ref No. \\
\hline \multirow[t]{2}{*}{ IDDM } & HLA & 6P & HLA-DR3 + DR4 susceptibility & $47-49$ \\
\hline & INS & $11 \mathrm{P}$ & RFLP linkage to insulin gene & $51-52$ \\
\hline \multirow[t]{3}{*}{ MODY } & Unknown & $20 q$ & $\begin{array}{l}\text { Linkage to ADA (adenosine deaminase) } \\
\text { gene }\end{array}$ & 53 \\
\hline & $\begin{array}{l}\text { Glukco- } \\
\text { kinase }\end{array}$ & $7 P$ & $\begin{array}{l}\text { "Missense mutation (G to C substitution) } \\
\text { in codon } 299\end{array}$ & 54 \\
\hline & & & $\begin{array}{l}\text { "Nonsense mutation ( } G \text { to } \mathrm{T} \text { substitution) } \\
\text { at codon } 279\end{array}$ & 55 \\
\hline \multirow[t]{3}{*}{ NIDDM } & INS & $11 p$ & $\begin{array}{l}\text { "TTC } \rightarrow \text { TTG substitution at residue } 25 \text { of } \\
\text { insulin gene } \beta \text { Chain (Insulin Chicago) }\end{array}$ & 11 \\
\hline & & & $\begin{array}{l}\text { "TTC } \rightarrow \text { TCC substitution at residue } 24 \text { of } \\
\text { insulin gene } \beta \text { chain (Insulin Los Angeles) }\end{array}$ & 12 \\
\hline & & & $\begin{array}{l}\text { "Leucine } \rightarrow \text { Valine substitution at residue } 3 \\
\text { of insulin } \alpha \text { chain (Insulin Wakayama) }\end{array}$ & $56-57$ \\
\hline $\begin{array}{l}\text { Secondary } \\
\text { DM }\end{array}$ & INSR & $19 \mathrm{P}$ & $\begin{array}{l}\text { "Decreased insulin receptor mRNA due } \\
\text { to missense and nonsense mutations }\end{array}$ & $58-60$ \\
\hline \multirow[t]{2}{*}{$\begin{array}{l}\text { MODY \& } \\
\text { Deafness }\end{array}$} & Multiple & $\begin{array}{l}\text { Mito- } \\
\text { chondrial } \\
\text { DNA }\end{array}$ & $\begin{array}{l}\text { *10.4 kb deletion (removes } \mathrm{OL} \text { of } \\
\text { mLNA replication) }\end{array}$ & 61 \\
\hline & & & $\begin{array}{l}\text { *A to } G \text { transition at nucleotide } 3,243 \\
\text { [tRNA }{ }^{\text {kearvoro }} \text { gene] }\end{array}$ & 62 \\
\hline
\end{tabular}

\section{Summary}

Several examples of molecular studies of hereditary endocrine disorders have been reviewed. These DNA studies have revealed the location and types of molecular derangements causing these diseases. The mutations discovered have in turn explained the alterations in the hormone products. These same methods should reveal the basis of many other endocrine disorders for which specific DNA probes are or will become available. I thank the Research Society for Growth Disturbance in Children for inviting me.

\section{Acknowledgements}

This work was supported in part by NIH grants DK35592, HD28819 and RR00095. The author thanks Pamela Grimm for preparing the manuscript. 


\section{References}

1. Malcolm ADB. The use of restriction enzymes in genetic engineering. Genet Eng 1989; 2: 129.

2. Burk RD et al . Characterization and evolution of a single-copy sequence from the human Y chromosome. Molec Cell Biol 1985; 5: 576.

3. Butler MG et al. A child with $45, \mathrm{X} / 46, \mathrm{X}$, $\operatorname{del}(\mathrm{Y})(\mathrm{q} 12)$ identified with a $\mathrm{Y}$ specific probe. Fertility and Sterility 1986; 46: 718.

4. Phillips JA III. Inherited defects in growth hormone synthesis and action. In: The Metabolic Basis of inherited Disease, seventh edition. C.R.Scriver, A.L.Beaudet, W. S.Sly, and D.Valle (eds), McGraw-Hill Information Services Company, New York, 7th edition, 1994; in press.

5. Vnencak-Jones CL, Phillips JA III. Hot spots for growth hormone gene deletions in homologous regions outside of alu repeats. Science 1990; 250: 1745-48.

6. Tager $\mathrm{H}$ et al. A structurally abnormal insulin causing diabetes. Nature 1979; 281 : 122.

7. Given $\mathrm{BD}$ et al. Diabetes due to secretion of an abnormal insulin. N Engl J Med 1980; 302: 120.

8. Olefsky JM et al. Characterization of a mutant insulin species. J Biol Chem 1980; 255: 6098.

9. Schoebron $\mathrm{S}$ et al. Three mutant insulins in man. Nature 1983; 302: 540.

10. Kwok SCM et al. Loss of a restriction endonuclease cleavage site in the gene of a structurally abnormal human insulin. Biochem Biophys Res Comm 1981; 98: 844.

11. Kwok SCM et al. Identification of a point mutation in the HIG giving rise to a structurally abnormal insulin (insulin Chicago). Diabetes 1983; 32: 872.

12. Haneda $\mathrm{M}$ et al. Studies on mutant HIG: Identification and sequence analysis of a gene encoding (Ser $\mathrm{B}_{24}$ ). Proc Natl Acad Sci (USA) 1983; 80: 6366.
13. Cooper DN et al. An estimate of unique DNA sequence heterozygosity in the human genome. Hum Genet 1985; 69: 201.

14. Phillips JA III. Clinical applications of gene mapping and diagnosis. In: Progress in Medical Genetics, New Series, B. Childs, N.A.Holtzman, H.H.Kazazian, and D. Valle (eds), 1987: 68-99.

15. Repaske DR et al. Molecular analysis of autosomal dominant neurohypophyseal diabetes insipidus. J. Clin. Endocrinol. \& Metab. 1990; 70: 752-7.

16. Arnheim N, White T, Rainey WE. The application of PCR: Organismal and population biology. BioScience 1990; 40: 174.

17. Eisenstein $\mathrm{BI}$. The polymerase chain reaction: A new method of using molecular genetics for medical diagnosis. $\mathrm{N}$ Engl J Med 1990; 322: 178.

18. Cogan JD, Phillips JA III. Polymerase chain reaction and DNA sequencing. In: Inferfilits and Reproductive Medicine Clinics of North America, LC Layman (ed) 5: 29-51, 1994.

19. Sanger $F$ et al. DNA sequencing with chain-terminating inhibitors. Proc Natl Acad Sci (USA) 1977; 74: 5463.

20. Ridell DC, Mallonee R, Phillips JA III, Parks JS, Sexton JA, Hamerton JL. Chromosomal assignment of human sequences encoding arginine vasopressinneurophysin II and growth hormone releasing factor. Somatic Cell and Mol Genet 1985; 11: 189-95.

21. Ito M, Mori Y, Oiso Y, Saito H. A single base substitution in the coding region for neurophysin II associated with familial central diabetes insipidus. J Clin Invest 1991; 87: 725-8.

22. Bahnsen U, Oosting P, Swaab DF, Nahke $P$, Richter D, Schmale H. A missense mutation in the vasopressin-neurophysin precursor gene cosegregates with human autosomal dominant neurohypophyseal diabetes insipidus. EMBO J 1992; 11: 19-23.

23. Krishnamani MRS, Phillips JA III, Copeland KC. Detection of a novel arginine vasopressin defect by dideoxy fingerprint- 
ing. J Clin Endo \& Metab. 1993; 77: 596-8. 24. Yuasa $H$, Ito $M$, Nagasaki $H$, Oiso $Y$, Miyamoto S, Sasaki N, Saito H. Glu-47, which forms a salt bridge between neurophysin-II and arginine vasopressin, is deleted in patients with familial central diabetes insipidus. J Clin Endocrinol \& Metab 1993; 77: 600-4.

25. Illig R. Growth hormone antibodies in patients treated with different preparations of human growth hormone (HGH). J Clin Endocrinol Metab 1970; 31: 679-88.

26. Illig R, Prader A, Ferrandez A, Zachmann M. Hereditary prenatal growth hormone deficiency with increased tendency to growth hormone antibody formation In Endokrinologue der Enrwicklung und Restung. J. Kracht, editor. 1970: 246.

27. Illig R, Prader A, Ferrandez A, Zachmann M. Hereditary prenatal growth hormone deficiency with increased tendency to growth hormone antibody formation ("Atype" isolated growth hormone deficiency). Acta Pediatr Scand Suppl 1971; 60: 607.

28. Phillips JA III, Hjelle BL, Seeburg PH, Zachmann M. Molecular basis for familial isolated growth hormone deficiency. Proc Natl Acad Sci USA. 1981; 78: 6372-5.

29. Laron Z, Kelijman M, Pertzelan A, Keret R, Shoffner JM, Parks JS. Human growth hormone gene deletion without antibody formation or growth arrest during treatment-A new disease entity. Isr J Med Sci 1985; 21: 999-1006.

30. Vnencak-Jones CL, Phillips JA III. Hot spots for growth hormone gene deletions in homologous regions outside of Alu repeats. Science 1990; 250: 1745-8.

31. Vnencak-Jones CL, Phillips JA III, De-fen W. Use of polymerase chain reaction in detection of growth hormone gene deletions. J Clin Endocrinol \& Metab 1990; 70: 1550-3.

32. Kamijo T, Phillips JA III. Detection of molecular heterogeneity in GH-1 gene deletions by analysis of polymerase chain reaction amplification products. J Clin Endocrinol \& Metab 1992; 74: 786-9.
33. Mullis PE, Akinci A, Kanaka $\mathrm{CH}$, Eble A, Brook CGD. Prevalence of human growth hormone-1 gene deletions among patients with isolated growth hormone deficiency from different populations. Ped Res 1992; 31: 532-4.

34. Duquesnoy P, Amselem S, Gourmelen M, LeBouc Y, Goossens M. A frameshift mutation causing isolated growth hormone deficiency type 1A. Am J Hum. Genet. 1990; 47: A110.

35. Cogan JD, Phillips JA III, Sakati N, Frisch H, Schober E, Milner RDG. Heterogenous growth hormone $(\mathrm{GH})$ gene mutations in familial GH deficiency. J Clin Endocrinol \& Metab 1993; 76: 1224-8.

36. Phillips JA III. Molecular biology of growth hormone receptor dysfunction. Acta Paediatr Suppl 1992; 383: 127.

37. Godowski PJ, Leung DW, Meacham LR et al. Characterization of the human growth hormone receptor gene and demonstration of a partial gene deletion in two patients with Laron-type dewarfism. Proc Natl Acad Sci USA 1989; 86: 8083.

38. Amselem S, Sobrier ML, Duqesnoy $\mathrm{P}$, Rappaport R, Postel-Vinay M-C, Gourmelen $\mathrm{M}$ et al. Recurrent nonsense mutations in the growth hormone receptor from patients with Loron dwarfism. J Clin Invest 1991; 87: 1098.

39. Amselem S, Duquesnoy P, Attree O, Novelli G, Bousnina S, Postel-Vinay M-C et al . Laron dwarfism and mutation of the growth hormone-receptor gene. N Engl J Med 1989; 321-989.

40. Duquesnoy P, Sobrier ML, Amselem S, Goossens M. Defective membrane expression of human growth hormone $(\mathrm{GH})$ receptor causes Laron-type GH insensitivity syndrome. Proc Natl Acad Sci USA 1991; 88: 10272.

41. Rosenbloom AL, Guevara-Aguirre J, Rosenfeld RG, Fielder PJ. The little women of Loja-growth hormone-receptor deficiency in an inbred population of southern Ecuador. N Engl J Med 1990; 323: 1367.

42. Berg MA, Guevara-Aguirre J, Rosenbloom 
AL, Rosenfeld RG, Francke U. Mutation creating a new splice site in the growth hormone receptor genes of 37 Ecuadorian patients with Laron syndrome. Hum Mutat 1992; 1: 24.

43. Tatsumi K-1 Kiyai K, Notomi T, Kaibe K, Amino N, Miuno Y, Kohno H. Cretinism with combined hormone deficiency caused by a mutation in the Pit-1 gene. Nature Genet 1992; 1: 56.

44. Radovick S, Nations M, Du Y, Berg LA, Weintraub BD, Wondisford FE. A mutation in the POU-homeodomain of Pit-1 responsible for combined pituitary hormone deficiency. Science 1992; 257: 1115.

45. Wit JM, Drayer NM, Jansen M, Walenkamp MJ, Hackeng WHL, Thijssen JHH, Van den Brande JL. Total deficiency of growth hormone and prolactin, and partial deficiency of thyroid stimulating hormone in two Dutch families: a new variant of hereditary deficiency. Hormone Res 1989; 32: 170.

46. Pfaffle RW, DiMattia GE, Parks JS, Brown MR, Wit JM, Jansen M, Van der Nat H, Van den Brande JL, Rosenfeld MG, Ingraham HA. Mutation of the POU-specific domain of Pit-1 and hypopituitarism without pituitary hypoplasia. Science 1992; 257: 1118.

47. Singal DP, Blajchman MA. Histocompatibility (HL-A) antigens. Lymphocytotoxic Antibodies and Tissue Antibodies in Patients with Diabetes Mellitus. Diabetes 1973; 22: 429-32.

48. Wolf E, Spencer KM, Cudworth AG. The genetic susceptibility of type 1 (insulindependent) diabetes: analysis of the HLADR association. Diabetologia 1983; 24: 22430.

49. Nepom BS, Palmer J, Kim SJ, Hansen JA, Holbeck SL, Nepom GT. Specific genomic markers for the HLA-DQ subregion discriminate between $\mathrm{DR}+4$ insulindependent diabetes mellitus and $\mathrm{DR}+4$ seropositive rheumatoid arthritis. J Exp Med 1986; 164: 345-50.

50. Bell GI, Horita S, Karam JH. A polymor- phic locus near the human insulin gene is associated with insulin-dependent diabetes mellitus. Diabetes 1984; 33: 176-83.

51. Julier C, Hyer RN, Devies J, Merlin F, Soularue $\mathrm{P}$, Briant $\mathrm{L}$, et al. Insulin-IGF2 region on chromosome $11 \mathrm{p}$ encodes a gene implicated in HLA-DR4-dependent diabetes susceptibility. Nature 1991; 354: 155-9.

52. Bowden DW, Gravius TC, Akots G, Fajans SS. Identification of genetic markers flanking the locus for maturity-onset diabetes of the young on human chromosome 20 . Diabetes 1992; 41: 88-92.

53. Bowden DW, Gravius TC, Akots G, Fajans SS. Identification of genetic markers flanking the locus for maturity-onset diabetes of the young on human chromosome 20 . Diabetes 1992; 41: 88-92.

54. Stoffel M, Patel P, Lo Y-MD, Hattersley AT, Lucassen AM, Page R, et al. Missense glucokinase mutation in maturity-onset diabetes of the young and mutation screening in late-onset diabetes. Nature Genet 1992; 2: 153-6.

55. Vionnet N, Stoffel M, Takeda J, Yasuda K, Bell GI, Zouali H, et al. Nonsense mutation in the glucokinase gene cause earlyonset non-insulin dependent diabetes mellitus. Nature 1992; 356: 721-2.

56. Nanjo K, Miyano M, Kondo M, Sanke T, Nishimura S, Miyamura $\mathrm{K}$ et al. Insulin Wakayama: Familial mutant insulin syndrome in Japan. Diabetologia 1987; 30: 87-92.

57. Awata T, Iwamoto Y, Matsuda A, Kuzuya $T$. Identification of nucleotide substitution in gene encoding $\left(\mathrm{leu}^{\mathrm{A} 3}\right)$ insulin in third Japanese familiy. Diabetes 1988; 37: 106870.

58. Muller-Wieland D, Taub R, Tewari DS, Kriauciunas M, Sethu S, Reddy K, et al. Insulin-receptor gene and its expression in patients with insulin resistance. Diabetes 1989; 38: 31-8.

59. Kadowaki T, Kadowaki H, Rechler MM, Serrano-rios M, Roth J, Gorden $\mathrm{P}$, et al . Five mutant alleles of the insulin receptor gene in patients with genetic forms of insu- 
lin resistance. J Clin Invest 1990; 86: 254-64. 60. Longo N, Langley SD, Griffin LD, Elsas II LJ. Reduced mRNA and anonsense mutation in the insulin-receptor gene produce heritable severe insulin resistance. Am J Hum Genet 1992; 50: 998-1007.

61. Ballinger SW, SHoffner JM, Hedaya EV, Trounce I, Polak MA, Koontz DA, et al. Maternally transmitted diabetes and deafness associated with a $10.4 \mathrm{~kb}$ mitochondrial DNA deletion. Nature Genet 1992; 1: 11-5.
62. vandenOuweland JMW, Lemkes HHPJ, Ruitenbeck W, Sandkuijl LA, deVijlder MF, Struyvenberg PAA, et al. Mutation in mitochondrial tRNA ${ }^{\text {leu(UUR) }}$ gene in a large pedigree with maternally transmitted type II diabetes mellitus and deafness. Nature Genet 1992; 1: 368-71.

63. Hughes MR et al. Point mutations in the human vitamin $\mathrm{D}$ receptor gene associated with hypocalcemic rickets. Science 1988; 242: 1702-5. 